\title{
The Potential Use of Nephelium lappaceum Seed as Coagulant-Coagulant Aid in the Treatment of Semi-Aerobic Landfill Leachate
}

\author{
Hamidi Abdul Aziz ${ }^{1,2, *(\mathbb{D})}$, Nur Syahirah Rahmat ${ }^{1}$ and Motasem Y. D. Alazaiza ${ }^{3}$ (D) \\ 1 School of Civil Engineering, Engineering Campus, Universiti Sains Malaysia, Nibong Tebal 14300, Malaysia; \\ nursyahirahrahmat92@gmail.com \\ 2 Solid Waste Management Cluster, Science and Technology Research Centre, Engineering Campus, \\ Universiti Sains Malaysia, Nibong Tebal 14300, Malaysia \\ 3 Department of Civil and Environmental Engineering, College of Engineering (COE), \\ A'Sharqiyah University (ASU), Ibra 400, Oman; my.azaiza@gmail.com \\ * Correspondence: cehamidi@usm.my
}

Citation: Aziz, H.A.; Rahmat, N.S.; Alazaiza, M.Y.D. The Potential Use of Nephelium lappaceum Seed as Coagulant-Coagulant Aid in the Treatment of Semi-Aerobic Landfill Leachate. Int. J. Environ. Res. Public Health 2022, 19, 420. https://doi.org/ 10.3390/ijerph19010420

Academic Editor: Paul B. Tchounwou

Received: 18 November 2021

Accepted: 23 December 2021

Published: 31 December 2021

Publisher's Note: MDPI stays neutral with regard to jurisdictional claims in published maps and institutional affiliations.

Copyright: (C) 2021 by the authors. Licensee MDPI, Basel, Switzerland. This article is an open access article distributed under the terms and conditions of the Creative Commons Attribution (CC BY) license (https:// creativecommons.org/licenses/by/ $4.0 /)$.

\begin{abstract}
Chemical-based coagulants and flocculants are commonly used in the coagulationflocculation process. However, the drawbacks of using these chemical materials have triggered researchers to find natural materials to substitute or reduce the number of chemical-based coagulants and flocculants. This study examines the potential application of Nephelium lappaceum seeds as a natural coagulant-coagulant aid with Tin (IV) chloride $\left(\mathrm{SnCl}_{4}\right)$ in eliminating suspended solids (SS), colour, and chemical oxygen demand (COD) from landfill leachate. Results showed that the efficiency of Nephelium lappaceum was low when used as the main coagulant in the standard jar test. When $\mathrm{SnCl}_{4}$ was applied as a single coagulant, as much as $98.4 \%$ of SS, $96.8 \%$ of colour and $82.0 \%$ of COD was eliminated at an optimal dose of $10.5 \mathrm{~g} / \mathrm{L}$ and $\mathrm{pH}$ 7. The higher removal efficiency of colour $(88.8 \%)$ was obtained when $8.40 \mathrm{~g} / \mathrm{L}$ of $\mathrm{SnCl}_{4}$ was applied with a support of $3 \mathrm{~g} / \mathrm{L}$ of Nephelium lappaceum. When $\mathrm{SnCl}_{4}$ was utilised as a coagulant, and Nephelium lappaceum seed was used as a flocculant, the removal of pollutants generally improved. Overall, this research showed that Nephelium lappaceum seed is a viable natural alternative for treating landfill leachate as a coagulant aid.
\end{abstract}

Keywords: landfill leachate; coagulation-flocculation; Nephelium lappaceum; COD; solid waste

\section{Introduction}

Landfilling is a very famous, recognised, and effective method for municipal solid waste management globally, owing to its low cost and simple operational mechanisms [1-3]. Landfill leachate is one of the major issues of landfilling method [3]. Leachate is usually generated by water infiltration through the waste; hence, it often includes suspended or dissolved solids from the disposed of materials. Generally, leachate is characterised in terms of $\mathrm{pH}$, total suspended solids (TSS), dissolved oxygen (DO), chemical oxygen demand (COD), biological oxygen demand (BOD), total Kjeldahl nitrogen (TKN), ammonium nitrogen $\left(\mathrm{NH}_{3}-\mathrm{N}\right)$, heavy metals, and others [4]. The composition of the leachate and the standard effluent quality vary by landfill location and legislation. The composition of leachate is affected by a number of parameters, including waste content, local meteorological conditions, landfill physicochemical conditions, and landfill age [5]. The structure and characteristics of the leachate are the most important elements influencing treatment method selection [6,7].

Biological treatment has proved its efficiency in treating different leachate types [8]. However, for old leachate with high COD and ammonium concentrations, numerous heavy metals, and low biodegradability (high COD/ BOD ratio), the efficacy of this approach did not show good removal results [9]. On the other hand, old leachate was found to be removed better using chemical and physical methods as compared to young leachate $[10,11]$. 
In general, it is easy to predict the quantity of long-term leachate; however, since the precipitation affects the short-term leachate, it is difficult to predict its quantity [12].

Generally, at the early stages of leachate production from waste decomposition, leachate has a large content of $\mathrm{BOD}_{5}$, biodegradable and non-biodegradable compounds like volatile fatty acids [11]. However, the leachate from old landfills typically contains a significant percentage of non-biodegradable compounds such as fulvic and humic-like chemicals [13]. Furthermore, inorganic molecules such as $\mathrm{NH}_{3}-\mathrm{N}$ are produced by the hydrolysis and fermentation of nitrogen-containing fractions of biodegradable waste substrates in stabilised leachate formed from older landfills. [14]. When the waste is stabilised, and leachate is collected and transported for treatment, washout influences the accumulating concentration of $\mathrm{NH}_{3}$ [15].

Physicochemical methods are commonly employed to pre-treat or polish the leachate. Coagulation-flocculation is a well-known chemical technique for leachate pre-treatment [16] This method is normally used to remove suspended particles and recalcitrant compounds like humic acids, heavy metals, polychlorinated biphenyls (PCBs), and absorbable organic halides from the leachate (AOX). The mechanism of the pre-treatment method primarily entails charge neutralisation between the negative charge colloids and cationic hydrolysis products, followed by impurity amalgamation by flocculation [17]. The main parameters removed by this method are total suspended solids (TSS) and colloidal particles [18].

Several materials are used as coagulants and flocculants in the coagulation-flocculation process, where inorganic metal salts are extensively used for this purpose. Excessive use of these inorganic metal salts, on the other hand, may have negative impacts on the environment and represent a health concern [19]. To lessen and remove the negative impacts on living beings and the environment, natural coagulants/flocculants are critical to be developed and applied for landfill leachate treatment.

Malaysia is a tropical country that has a wide variety of fruits. As a result, numerous food companies make canned fruits to take advantage of the availability. In Malaysia and Thailand, the Nephelium lappaceum canning industry is well-established, and it involves the manufacture of Nephelium lappaceum fruits in syrup [20]. The Nephelium lappaceums are deseeded during the canning process, and the seeds are generally discarded as waste by-products. It is, therefore, beneficial to value add the application of the Nephelium lappaceum seed from being just disposed of. Zurina et al. [20] used Nephelium lappaceum seed polysaccharide as a natural coagulant to remove water turbidity. However, to the author's knowledge, no published research has specifically focused on the use of Nephelium lappaceum seed as a natural coagulant or flocculant in the treatment of landfill leachate.

The main objective of this study was to scrutinise the effectiveness of using Nephelium lappaceum seed as a natural coagulant in leachate treatment. Specifically, Nephelium lappaceum seed was used in two states; where the first state involved the Nephelium lappaceum seed as a sole coagulant, whereas the second state used the Nephelium lappaceum seed as a flocculant associated with Tin (IV) chloride $\left(\mathrm{SnCl}_{4}\right)$. The application of Nephelium lappaceum seed combined with $\mathrm{SnCl}_{4}$ has not been used in leachate treatment to date. The target parameters were suspended solids (SS), colour, and COD, which generally present at high concentrations in many old landfill sites.

\section{Materials and Methods}

\subsection{Sampling and Characterisation of Leachate}

The case study leachate samples were taken from one of the old landfills in Malaysia, i.e., the Alor Pongsu Landfill Site (APLS). APLS is one of the existing landfills in Malaysia located in Bagan Serai, Perak, with coordinates of $5^{\circ} 05^{\prime} 00.6^{\prime \prime} \mathrm{N} 100^{\circ} 35^{\prime} 53.1^{\prime \prime}$ E. APLS was constructed in 2000 as an open dumping site and categorised as a stabilised and matured landfill as it has been operating for more than 10 years [21]. The total area of APLS is about 10 acres where it consists of a large dumping site and three leachate collection ponds. These ponds are in an anaerobic condition which acts as raw collection ponds. Leachate samples were collected six times within four consecutive months, starting from January 
2020 to April 2020. All procedures of sampling (grab method), storage, and preservation of landfill leachate followed the Standard Methods for the Examination of Water and Wastewater [22]. The $\mathrm{pH}$, temperature, dissolved oxygen (DO), and total dissolved solids (TDS) were analysed on-site using YSI 556-Probe System. All samples were transported to the laboratory and maintained in a cool chamber at $4{ }^{\circ} \mathrm{C}$ for further use. This procedure is to minimise any reaction, including chemical and biological reactions that may affect leachate properties [2]. The COD, $\mathrm{BOD}_{5}, \mathrm{NH}_{3}-\mathrm{N}$, colour, and SS were conducted in the laboratory immediately upon arrival.

\subsection{Extraction and Characterisation of Nephelium lappaceum Seed}

Fresh Nephelium lappaceum fruits were bought from a roadside store at Kulim, Kedah, Malaysia. The fruits were deseeded and washed using tap water before drying them in an oven at a temperature of $105^{\circ} \mathrm{C}$ for 10 to $15 \mathrm{~min}$. This is to ensure easy peeling off of the seed coat of Nephelium lappaceum seeds, thus preventing the increase of moisture content in the seeds that may damage its natural content. The seeds were then crushed into powder by using a domestic blender and kept in airtight containers until further use.

A $50 \mathrm{~g}$ package of Nephelium lappaceum seed powder was mixed with one litre of distilled water to produce $50 \mathrm{~g} / \mathrm{L}$ of Nephelium lappaceum seed stock solution. After that, the mix solution was blended again for two minutes. The suspension was then filtered using muslin cloth in a beaker to become the stock solution before being characterised in terms of $\mathrm{pH}$, zeta potential, molecular weight, particle size, surface morphology, and functional groups. The molecular weight of Nephelium lappaceum seed was determined by using Malvern Zetasizer Nano ZS. Surface morphology was conducted using ZEISS SUPRA 35VP Field Emission Scanning Electron. Meanwhile, determination of the functional group of Nephelium lappaceum seed was conducted using Perkin-Elmer System 2000 FTIR spectrometer. $\mathrm{SnCl}_{4}$ as the main coagulant was the analytical grade of pentahydrate, $\mathrm{SnCl}_{4} .5 \mathrm{H}_{2} \mathrm{O}$ with $98 \%$ purity grade, supplied by Telaga Madu Sdn. Bhd. Malaysia.

\subsection{Coagulation-Flocculation Experiment}

A jar test apparatus was used to conduct the coagulation-flocculation procedures. The jar test device has six agitators together with $2.5 \mathrm{~cm} \times 7.5 \mathrm{~cm}$ rectangular blades for stirring and mixing. The velocity of the instrument and mixing duration were controlled manually. Before the coagulation-flocculation process, samples of landfill leachate were taken from the storage chamber and placed outside until they were conditioned to room temperature. After that, the sample was agitated thoroughly to ensure uniform mixing. Six $1000 \mathrm{~mL}$ beakers were filled with $500 \mathrm{~mL}$ of agitated sample. The $\mathrm{pH}$ of the samples was adjusted with $3 \mathrm{M} \mathrm{HCl}$ or $3 \mathrm{M} \mathrm{NaOH}$ until the desired $\mathrm{pH}$ was obtained. The desired $\mathrm{pH}$ was determined according to the optimum dosage, as shown in the next section.

The coagulation-flocculation process involves three important stages: rapid mixing, slow mixing, and settlement. A combination of fast mixing (100 rpm in $8 \mathrm{~min}$ ), slow mixing (30 rpm in $20 \mathrm{~min}$ ), and a settlement for $30 \mathrm{~min}$ was used for the experiments using Nephelium lappaceum seed as the main coagulant [23]. For the studies employing $\mathrm{SnCl}_{4}$ as coagulant without and with Nephelium lappaceum seed as flocculant, the rapid mixing of $200 \mathrm{rpm}$ in $1.5 \mathrm{~min}$, slow mixing of $40 \mathrm{rpm}$ in $20 \mathrm{~min}$, and settlement for 20 min were used [24]. The removal efficiencies of key parameters such as SS, colour, and COD in landfill leachate samples were used to estimate the efficacy of the coagulation-flocculation process. Equation (1) [25] was used to compute the removal efficiencies of each pollutant:

$$
\operatorname{Removal}(\%)=\left[\left(\mathrm{C}_{\mathrm{i}}-\mathrm{C}_{\mathrm{f}}\right) / \mathrm{C}_{\mathrm{i}}\right] \times 100
$$

where $C_{i}$ : is the initial concentration of the samples, $C_{f}$ : is the final concentration of samples.

\subsection{Determination of Optimum $\mathrm{pH}$ and Coagulant Dosage}

Preliminary tests were carried out to obtain the pre-determined dosage and $\mathrm{pH}$ conditions. A preliminary test for Nephelium lappaceum seed was carried out using various 
dosages (0.5-15 g/L) of Nephelium lappaceum on raw leachate, whereas for $\mathrm{SnCl}_{4}$, dosages between 3.5 to $17.5 \mathrm{~g} / \mathrm{L}$ were used. Then, the pre-determined dosages obtained were applied in varied $\mathrm{pH}$ landfill leachate from 2 to 12 to determine the best $\mathrm{pH}$ value for both Nephelium lappaceum seed and $\mathrm{SnCl}_{4}$. Together with this experiment, a $\mathrm{pH}$ control experiment was also conducted by adjusting the $\mathrm{pH}$ of the sample without any coagulant. This control process was carried out to ensure that the removal of the pollutant was not made solely by acids or alkalis.

Once the optimum $\mathrm{pH}$ was determined, a new set of experiments were carried out to determine the optimum dosages of Nephelium lappaceum seed using different dosages varying from 0 (as a control) to $3 \mathrm{~g} / \mathrm{L}$. Meanwhile, different dosages of $\mathrm{SnCl}_{4}$ varying from 0 (as control) to $17.5 \mathrm{~g} / \mathrm{L}$ have been applied to the samples with the optimum $\mathrm{pH}$ value of $\mathrm{SnCl}_{4}$.

A jar test experiment was conducted to evaluate the use of $\mathrm{SnCl}_{4}$ as a coagulant in conjunction with Nephelium lappaceum seed as a flocculant. These were undertaken at different $\mathrm{SnCl}_{4}$ and Nephelium lappaceum seed dosages. Different dosages of $\mathrm{SnCl}_{4}$ were used, ranging from $5.60 \mathrm{~g} / \mathrm{L}$ to $8.75 \mathrm{~g} / \mathrm{L}$. For Nephelium lappaceum seed, the dosage was from $0 \mathrm{~g} / \mathrm{L}$ to $4 \mathrm{~g} / \mathrm{L}$. The same operating conditions for a jar test as before were applied.

\section{Results and Discussion}

\subsection{Landfill Leachate Compositions}

Table 1 shows the main characteristics of the raw leachate of APLS. The leachate has a temperature in the range of $26.48^{\circ} \mathrm{C}$ to $32.07^{\circ} \mathrm{C}$ with an average of $29.47^{\circ} \mathrm{C}$, which is within the permissible limit of below $40^{\circ} \mathrm{C}$ as stated by the Malaysia Environmental Quality Act 1974. The leachate has a $\mathrm{pH}$ of 8.04 to 8.90 , with an average of $\mathrm{pH} 8.59$. This represents an old type of leachate. A young landfill (up to 5 years) has a $\mathrm{pH}$ from 3.7 to 6.5 , whereas matured landfill has a $\mathrm{pH}$ higher than 7 . This is because young landfill leachate contains carboxylic acid and bicarbonate ions that contribute to the low $\mathrm{pH}$ [26]. The concentration of the dissolved oxygen was between 2.14 and $4.38 \mathrm{mg} / \mathrm{L}$ with an average of $3.17 \mathrm{mg} / \mathrm{L}$. The amount of DO in landfill leachate is usually low due to the various chemical pollutants as well as the high temperature that may restrain the concentration of oxygen in the landfill leachate [27]. COD value was between 2532 and $4215 \mathrm{mg} / \mathrm{L}$ with an average of $3440 \mathrm{mg} / \mathrm{L}$. This far exceeded the standard discharge limit of $400 \mathrm{mg} / \mathrm{L}$ [22]. COD level in APLS landfill leachate was slightly lower than that of the previous study [28]. This is due to numerous factors that may affect the COD level of the landfill leachate, like; landfill age, the solid waste compositions, site characteristics, and climate conditions [29]. Besides that, APLS is a matured and stabilised landfill as the leachate contains a higher COD level, which is below $4000 \mathrm{mg} / \mathrm{L}$ [21]. BOD 5 of landfill leachate from APLS ranged from 160 to $333 \mathrm{mg} / \mathrm{L}$ with an average of $241 \mathrm{mg} / \mathrm{L}$., also exceeding the standard discharge limit of $20 \mathrm{mg} / \mathrm{L}$. It can be concluded that the APLS is a stabilised landfill site as the $\mathrm{BOD}_{5}$ is less than $4000 \mathrm{mg} / \mathrm{L}$ [30]. The $\mathrm{BOD}_{5} / \mathrm{COD}$ ratio in leachate was about 0.070 within the range of 0.057 to 0.080 . In general, a mature and stabilised landfill has a lower fraction of $\mathrm{BOD}_{5} / \mathrm{COD}$, which is less than 0.1 due to the lower biodegradable fraction of organic pollutants in mature landfill leachate [21]. The low $\mathrm{BOD}_{5} / \mathrm{COD}$ ratio indicates that it would be difficult to treat the leachate using a biological process. $\mathrm{NH}_{3}-\mathrm{N}$ in APLS leachate was in the range of 1040 to $1357 \mathrm{mg} / \mathrm{L}$ and is slightly lower than the previous work [31]. The SS ranged from 350 to $604 \mathrm{mg} / \mathrm{L}$ and fell within the range of mature leachate. The leachate is negatively charged with a zeta potential reading of $-21.5 \mathrm{mV}$; hence the majority of particles in leachate have the tendency to repel each other. Therefore, a coagulant with zeta potential higher than $+21 \mathrm{mV}$ is needed to neutralise the charges of particles in leachate and aggregate them into large flocs [12]. A recent study by Ramli et al. [32] showed similar results for the leachate characteristics. Figure 1 shows the particle size distribution of the leachate sample. 
Table 1. Alor Pongsu Landfill Site (APLS) raw leachate characteristics.

\begin{tabular}{ccccc}
\hline Parameter & Min & Max & Average & Permissible Limit \\
\hline Temperature $\left({ }^{\circ} \mathrm{C}\right)$ & 26.48 & 32.07 & 29.47 & 40 \\
\hline $\mathrm{pH}$ & 8.04 & 8.90 & 8.59 & $6.0-9.0$ \\
\hline Total Dissolved Solids (g/L) & 8.532 & 9.950 & 9.440 & \\
\hline Dissolved Oxygen $(\mathrm{mg} / \mathrm{L})$ & 2.14 & 4.38 & 3.17 & 20 \\
\hline BOD5 $(\mathrm{mg} / \mathrm{L})$ & 160 & 333 & 241 & 400 \\
\hline COD $(\mathrm{mg} / \mathrm{L})$ & 2533 & 4215 & 3440 & 50 \\
\hline Ratio BOD $/ \mathrm{COD}$ & 0.057 & 0.080 & 0.070 & 100 \\
\hline Suspended Solids (mg/L) & 350 & 604 & 469 & 5 \\
\hline Colour $(\mathrm{PtCo})$ & 13750 & 18733 & 16829 & \\
\hline NH 3 -N & 1040 & 1357 & 1227 & \\
\hline Zeta Potential $(\mathrm{mV})$ & -22.4 & -20.7 & -21.5 & \\
\hline
\end{tabular}

*Average value for six samples taken from January to April 2020.

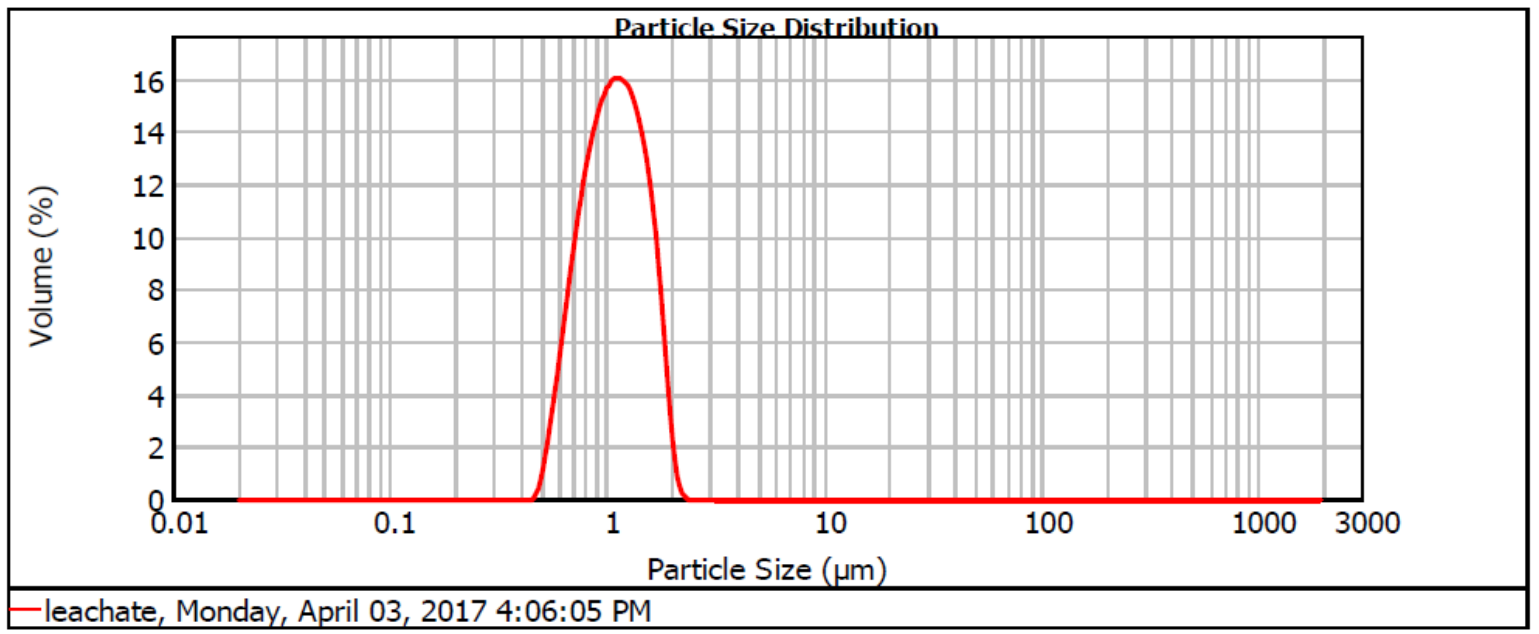

Figure 1. Particle size distribution for (a) landfill leachate.

\subsection{Characteristic of Nephelium lappaceum Seeds}

Nephelium lappaceum seed has an acidic condition (ranging between 3.56 and 5.36) with an average $\mathrm{pH}$ of $4.45 \pm 0.71$. Generally, Nephelium lappaceum is an acidic fruit. According to Arenas et al. [33], Nephelium lappaceum has a $\mathrm{pH}$ range from 4.6 to 5.5, of which the $\mathrm{pH}$ was similar to its seed. The Zeta potential of Nephelium lappaceum seed was recorded to be about $5.46 \pm 0.615 \mathrm{mV}$ at its natural $\mathrm{pH}$. By knowing its zeta potential, the Nephelium lappaceum seed is a cationic coagulant which means that it has a positively charged particle surface. Figure 2 shows the particle size distribution of Nephelium lappaceum.

The molecular weight of Nephelium lappaceum seed was measured at $3850 \mathrm{kDa}$. It was slightly higher if compared to Longan seed, where its molecular weight was $3280 \mathrm{kDa}$ [16]. The increase in molecular weight of the coagulant, according to Ebeling et al. [34], encourages more particles to adhere to each other by providing extended branches and channels, resulting in larger flocs in the coagulation-flocculation process. Nevertheless, different coagulants may have their own coagulation-flocculation behaviour despite their high molecular weight [6].

The functional group of Nephelium lappaceum seed was determined using an FTIR Spectrometer, and the results are given in Figure 3 and Table 2. It is shown that Nephelium lappaceum seed contains many functional groups such as alcohol $(\mathrm{O}-\mathrm{H})$, amide $(\mathrm{N}-\mathrm{H})$, and carboxylic groups $(\mathrm{C}=\mathrm{O})$. However, only certain functional groups play an important role 
in coagulation-flocculation processes. According to Zafar et al. [35], natural coagulant neutralises the particle charges and aggregates flocs through bridging mechanisms by biopolymers such as polysaccharides which can be found naturally in fruits and vegetables. Polysaccharides are one of the carbohydrate subgroups that contain carbon, hydrogen, and oxygen [36]. Furthermore, Aziz and Sobri [37] reported that carboxyl $(\mathrm{C}=\mathrm{O})$, hydroxyl $(\mathrm{O}-\mathrm{H})$, and amino (amine or amide) grouped together with polymeric chains have the capability to enhance flocculation through bridging. From the results, the content of $(\mathrm{O}-\mathrm{H})$, amide $(\mathrm{N}-\mathrm{H})$, and carboxylic groups $(\mathrm{C}=\mathrm{O})$ in Nephelium lappaceum seed are expected to serve as ion bridge or binding sites in coagulation-flocculation processes.

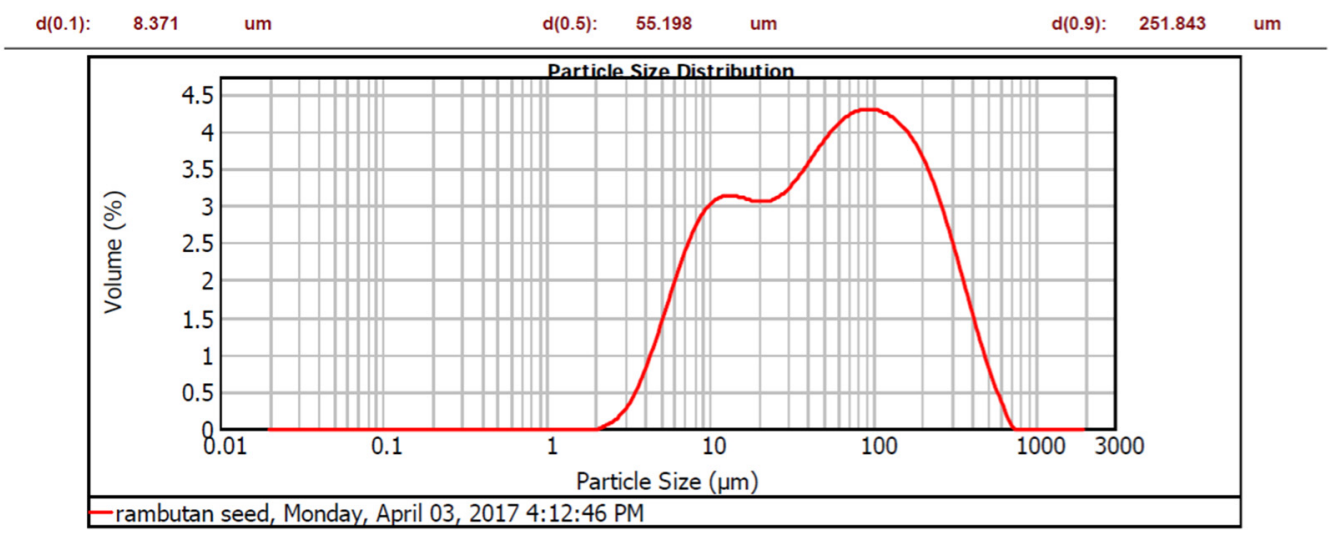

Figure 2. Particle size of Nephelium lappaceum seeds.

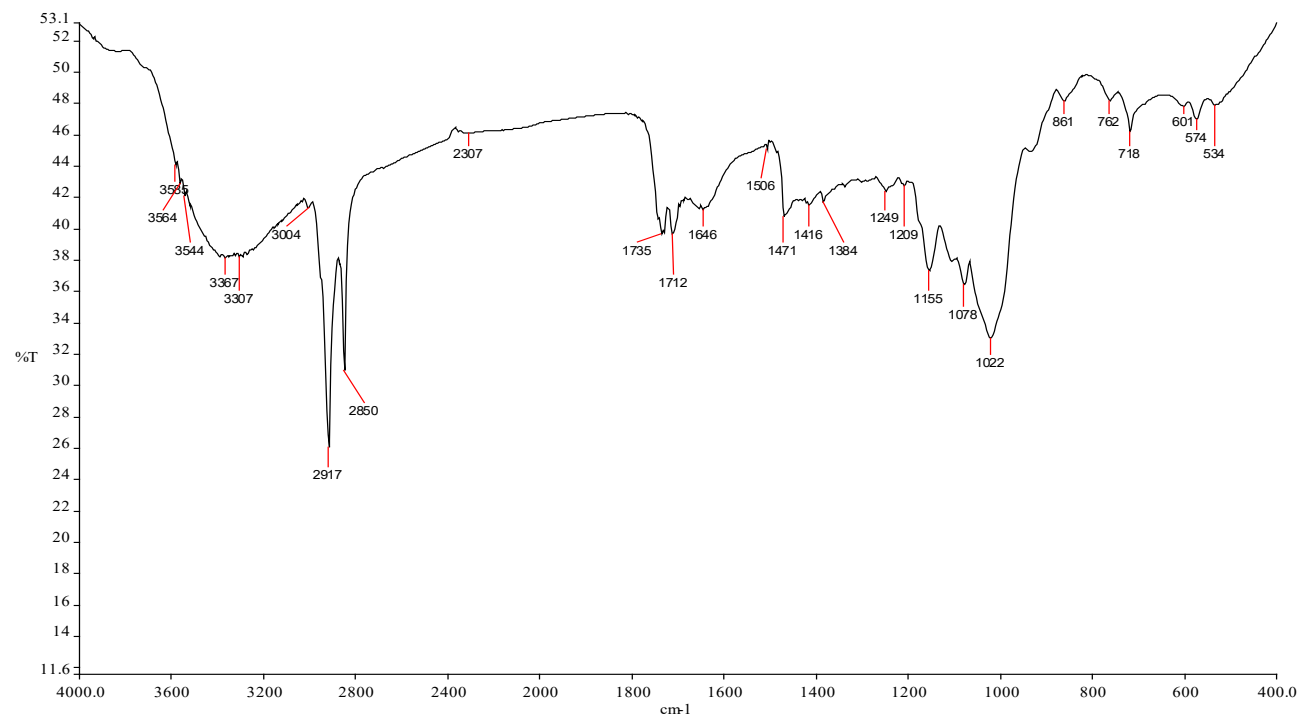

Figure 3. FTIR spectra of Nephelium lappaceum seed.

Table 2. Functional groups of Nephelium lappaceum seed.

\begin{tabular}{cccccc}
\hline Wavelength $\left(\mathbf{c m}^{-\mathbf{1}}\right)$ & Wavenumber Range & Intensity & Bond & Group Vibration & Functional Group \\
\hline 3585 & $3700-3584$ & Medium & O-H & Stretching & Alcohol \\
\hline 3564 & $3700-3500$ & Medium & N-H & Stretching & Amide \\
\hline 3544 & $3550-3200$ & Strong & O-H & Stretching & Alcohol \\
\hline 3367 & $3400-3300$ & Medium & N-H & Stretching & Aliphatic primary amine \\
\hline 3307 & $3300-2500$ & Strong & O-H & Stretching & Carboxylic acid \\
\hline
\end{tabular}


Table 2. Cont.

\begin{tabular}{|c|c|c|c|c|c|}
\hline Wavelength $\left(\mathrm{cm}^{-1}\right)$ & Wavenumber Range & Intensity & Bond & Group Vibration & Functional Group \\
\hline \multirow{2}{*}{3004} & $3000-2800$ & Strong & $\mathrm{N}-\mathrm{H}$ & Stretching & Amine salt \\
\hline & $3100-3000$ & Medium & $\mathrm{C}-\mathrm{H}$ & Stretching & Alkene \\
\hline 2917 & $3000-2800$ & Strong & $\mathrm{N}-\mathrm{H}$ & Stretching & Amine salt \\
\hline 2850 & $3000-2840$ & Medium & $\mathrm{C}-\mathrm{H}$ & Stretching & Alkane \\
\hline 2307 & $2280-2440$ & Medium & $\mathrm{P}-\mathrm{H}$ & Stretching & Phosphine \\
\hline 1735 & $1750-1735$ & Strong & $\mathrm{C}=\mathrm{O}$ & Stretching & $\delta$-lactone \\
\hline \multirow{4}{*}{1712} & $1725-1705$ & Strong & $\mathrm{C}=\mathrm{O}$ & Stretching & Aliphatic ketone \\
\hline & $1720-1706$ & Strong & $\mathrm{C}=\mathrm{O}$ & Stretching & Carboxylic acid \\
\hline & $1650-1580$ & Medium & $\mathrm{N}-\mathrm{H}$ & Bending & Amine \\
\hline & $1650-1566$ & Medium & $\mathrm{C}=\mathrm{C}$ & Stretching & Cyclic alkene \\
\hline 1506 & $1550-1500$ & Strong & $\mathrm{N}-\mathrm{O}$ & Stretching & Nitro compound \\
\hline 1471 & $1400-1480$ & Strong & $\mathrm{C}-\mathrm{O}$ & Stretching & Methylene \\
\hline \multirow{2}{*}{1416} & $1440-1395$ & Medium & $\mathrm{O}-\mathrm{H}$ & Bending & Carboxylic acid \\
\hline & $1420-1330$ & Medium & $\mathrm{O}-\mathrm{H}$ & Bending & Alcohol \\
\hline \multirow{3}{*}{1384} & $1415-1380$ & Strong & $\mathrm{S}=\mathrm{O}$ & Stretching & Sulfate \\
\hline & $1410-1380$ & Strong & $\mathrm{S}=\mathrm{O}$ & Stretching & Sulfonyl chloride \\
\hline & $1400-1000$ & Strong & $\mathrm{C}-\mathrm{F}$ & Stretching & Fluoro compound \\
\hline \multirow{2}{*}{1249} & $1342-1266$ & Strong & $\mathrm{C}-\mathrm{N}$ & Stretching & Aromatic amine \\
\hline & $1250-1020$ & Medium & $\mathrm{C}-\mathrm{N}$ & Stretching & Amine \\
\hline \multirow{3}{*}{1209} & $1275-1200$ & Strong & $\mathrm{C}-\mathrm{O}$ & Stretching & Alkyl aryl ether \\
\hline & $1225-1200$ & Strong & $\mathrm{C}-\mathrm{O}$ & Stretching & Vinyl ether \\
\hline & $1210-1163$ & Strong & $\mathrm{C}-\mathrm{O}$ & Stretching & Ester \\
\hline \multirow{4}{*}{1155} & $1170-1155$ & Strong & $\mathrm{S}=\mathrm{O}$ & Stretching & Sulphonamide \\
\hline & $1165-1150$ & Strong & $\mathrm{S}=\mathrm{O}$ & Stretching & Sulfonic acid \\
\hline & $1160-1120$ & Strong & $\mathrm{S}=\mathrm{O}$ & Stretching & Sulfone \\
\hline & $1205-1124$ & Strong & $\mathrm{C}-\mathrm{O}$ & Stretching & Tertiary alcohol \\
\hline 1078 & $1085-1050$ & Strong & $\mathrm{C}-\mathrm{O}$ & Stretching & Primary alcohol \\
\hline 1022 & $1050-1040$ & Strong & $\mathrm{CO}-\mathrm{O}-\mathrm{CO}$ & Stretching & Anhydride \\
\hline \multirow{2}{*}{861} & $880 \pm 20$ & Strong & $\mathrm{C}-\mathrm{H}$ & Bending & $1,2,4$-trisubstituted \\
\hline & $880 \pm 20$ & Strong & $\mathrm{C}-\mathrm{H}$ & Bending & 1,3-disubstituted \\
\hline \multirow{4}{*}{762} & $850-550$ & Strong & $\mathrm{C}-\mathrm{Cl}$ & Stretching & Halo compound \\
\hline & $780 \pm 20$ & Strong & $\mathrm{C}-\mathrm{H}$ & Bending & 1,2,3-trisubstituted \\
\hline & $755 \pm 20$ & Strong & $\mathrm{C}-\mathrm{H}$ & Bending & 1,2 -disubstituted \\
\hline & $750 \pm 20$ & Strong & $\mathrm{C}-\mathrm{H}$ & Bending & $\begin{array}{c}\text { Monosubstituted } \\
\text { benzene derivative }\end{array}$ \\
\hline 718 & $730-665$ & Strong & $\mathrm{C}=\mathrm{C}$ & Bending & Alkene \\
\hline \multirow{2}{*}{601} & $850-550$ & Strong & $\mathrm{C}-\mathrm{C}$ & Stretching & Halo compound \\
\hline & $690-515$ & Strong & $\mathrm{C}-\mathrm{Br}$ & Stretching & Halo compound \\
\hline 574 & $850-550$ & Strong & $\mathrm{C}-\mathrm{Cl}$ & Stretching & Halo compound \\
\hline \multirow{2}{*}{534} & $850-550$ & Strong & $\mathrm{C}-\mathrm{Cl}$ & Stretching & Halo compound \\
\hline & $600-500$ & Strong & C-I & Stretching & Halo compound \\
\hline
\end{tabular}


The surface morphology of Nephelium lappaceum seed is shown in Figure 4. According to FESEM micrographs, it can be seen that the Nephelium lappaceum seed surface has non-porous traits and mostly appears to be in globular shape. The surface morphology of Nephelium lappaceum seed appears similar to the Cassava peel, whereby it is smooth and globular in shape that covers the surface of Cassava peel [38]. It appears that most of the surfaces that contain starch are globular in shape due to the starch granules. Polysaccharides in the Nephelium lappaceum seed usually can be hydrolysed to hexose component, which is also known as starch. Moreover, Nephelium lappaceum seed has traces of alkaloids, sugar $(1.25 \%)$, starch (25\%), and ash (2\%). Starch is considered as one of the biopolymers that are needed in coagulation-flocculation as it comprises a mixture of two polymers of anhydrous glucose units and amylopectin. These biopolymers can enhance the mechanism of adsorption, charge neutralisation, as well as perform inter-particle bridging in coagulation-flocculation.

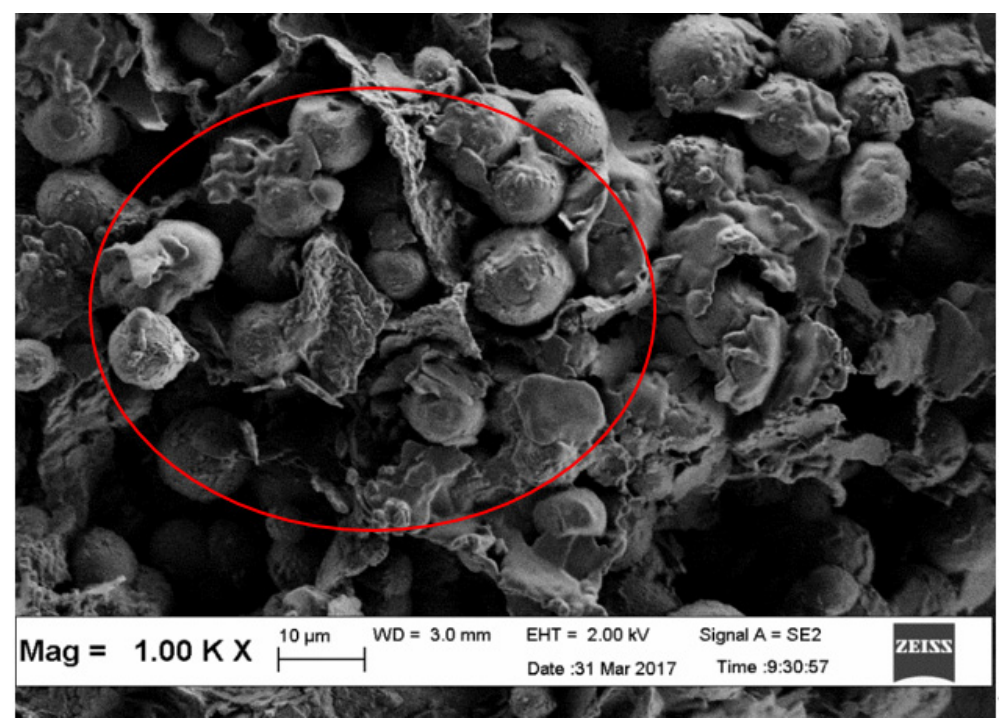

(a)

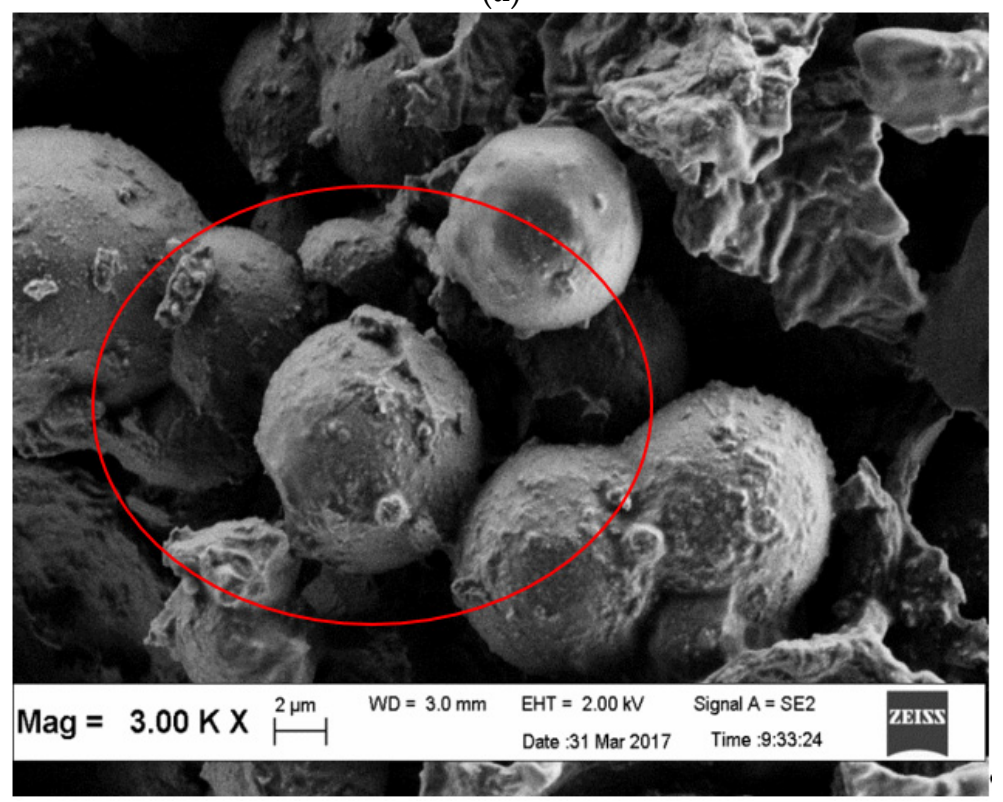

(b)

Figure 4. FESEM of Nephelium lappaceum seed. (a) 1000× magnification; (b) 3000× magnification. 


\subsection{Zeta Potential and Particle Size}

According to Omar et al. [39], pH affects the zeta potential and aggregation of particles. For this, the zeta potential and particle size of leachate and Nephelium lappaceum seed solution were studied throughout a $\mathrm{pH}$ range of 2 to 12. Figure 5 shows the zeta potential of leachate, which was decreased from $-9.53 \mathrm{mV}$ to $-29.5 \mathrm{mV}$ as $\mathrm{pH}$ increased from $\mathrm{pH} 2$ to 12 , respectively. This trend indicates that landfill leachate was completely affected by $\mathrm{pH}$. This observation is possibly due to the swift ionisation of both $\mathrm{OH}^{-}$and $\mathrm{H}^{+}$on the surface of particle size when the leachate $\mathrm{pH}$ was adjusted using acid $(\mathrm{HCl})$ and alkali $(\mathrm{NaOH})$ [39]. At $\mathrm{pH} 8$, the zeta potential was about $-22.4 \pm 1.95 \mathrm{mV}$, and this signified that the particle surface of leachate was naturally negatively charged. Thus, to neutralise the leachate surface charge, a positively charged coagulant with almost the same value as leachate particles was needed, and thus, the coagulation-flocculation process will then be highly effective $[40,41]$.

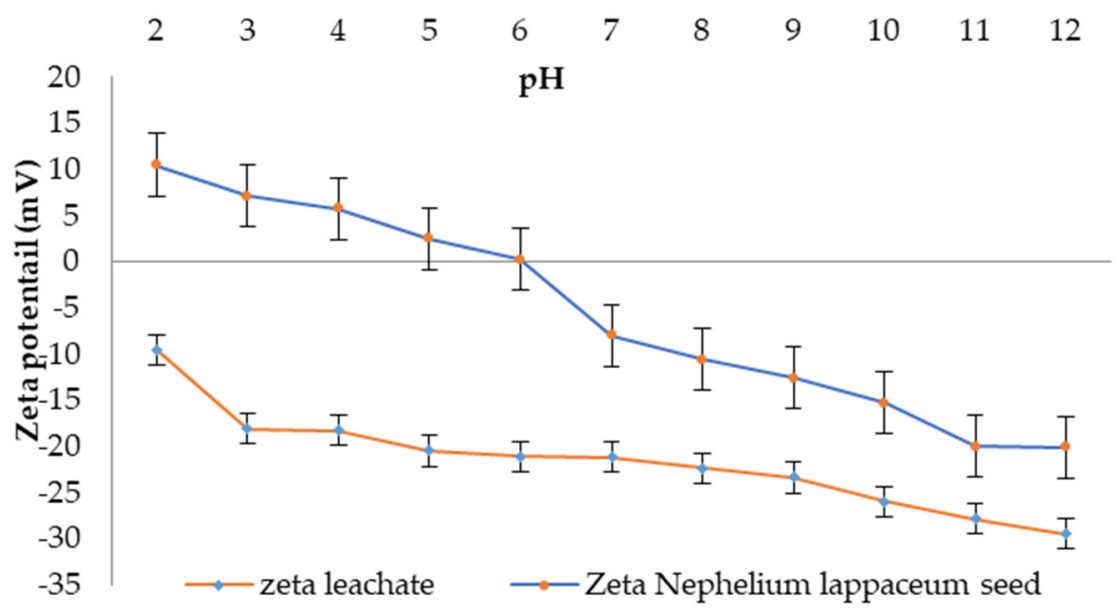

Figure 5. pH effect on Zeta potential of leachate.

Figure 6 shows the relationship between the particle size of leachate and $\mathrm{pH}$. Similar to zeta potential, leachate particle size also dropped as the $\mathrm{pH}$ increased. However, when the landfill leachate was added with $0.5 \mathrm{M} \mathrm{NaOH}$ in order to increase the $\mathrm{pH}$ from $\mathrm{pH} 8$ to $\mathrm{pH} 12$, the particle size subsequently decreased from 228.1 to $207.1 \mathrm{~d} . \mathrm{nm}$. According to Cao, et al. [39], the reaction of negatively charged ion, $\mathrm{OH}^{-}$from $\mathrm{NaOH}$, has interfered with the destabilisation of particles in the leachate by repelling each other and thus, made it impossible to form larger flocs. The particle size of landfill leachate increased from 228.1 d.nm to $9520 \mathrm{~d} . \mathrm{nm}$ when the $\mathrm{pH}$ of the leachate was altered to lower $\mathrm{pHs}$, which varied from $\mathrm{pH} 8$ to $\mathrm{pH}$ 2. This is most likely due to the fact that when the solution was acidic, the density of $\mathrm{H}^{+}$hydrolysates was extremely high, thus, dominate the charge neutralisation of the particles and forming a larger floc [39].

Kruszewski and Cyrankiewicz [42] stated that the aggregating agents $(\mathrm{KCl}$ or $\mathrm{HCl})$ caused a substantial increase in particle size intensity as chloride was presented in these aggregating agents, which is capable of promoting the aggregation process and thus enhancing the flocculation process. Hence, when the $\mathrm{pH}$ of leachate increased, the particle size also increased. Characterisation of Nephelium lappaceum seed in terms of zeta potential and particle size as a function of $\mathrm{pH}$ were performed to evaluate the suitability of Nephelium lappaceum seed to be used as a natural coagulant. The association between $\mathrm{pH}$ and zeta potential, as well as particle size of Nephelium lappaceum seed, are depicted in Figures 1 and 2, respectively. It can be seen that the trend of zeta potential of Nephelium lappaceum seed was also decreased as $\mathrm{pH}$ increased, which was identical to the behaviour of the leachate zeta potential trend. Between $\mathrm{pH} 2$ to $\mathrm{pH}$, the zeta potential of Nephelium lappaceum seed was observed to be in the positively charged surface, which was between 10.47 to 
$0.20 \mathrm{mV}$, respectively, and it was near to the point of zero charges (PZC). With a further increase of $\mathrm{pH}$, which was from $\mathrm{pH} 7$ to $\mathrm{pH} 12$, the zeta potential decreased drastically from -8.00 to $-20.1 \mathrm{mV}$. This signifies that Nephelium lappaceum seed became negatively charged surface after $\mathrm{pH}$ 6. During the coagulation-flocculation process, neutralisation of negatively charged surface of landfill leachate required positively charged coagulant.

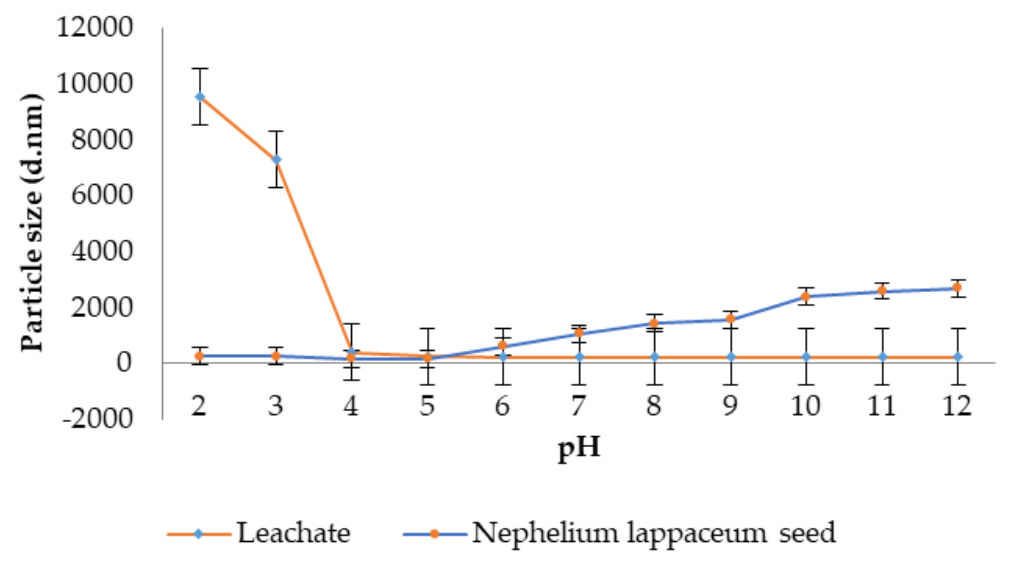

Figure 6. $\mathrm{pH}$ effect on particle size of leachate.

The trend of Nephelium lappaceum seed particle size with respect to $\mathrm{pH}$ was opposite to landfill leachate particles size. Overall, the particle size of Nephelim lappaceum seed increased as the $\mathrm{pH}$ increased. However, at $\mathrm{pH} 2$ to 5, the Nephelium lappaceum seed particle size decreased from 260.0 to $162.7 \mathrm{~d} . \mathrm{nm}$. This might be due to the fact that some negatively charged surface in the solution attracted with the positively charged ions that were hydrolysed from $\mathrm{HCl}$ acid [42], which was added in the Nephelium lappaceum solution to decrease the $\mathrm{pH}$ and thus, this had promoted the flocculation of particles. Furthermore, when $\mathrm{pH}$ increased from its natural $\mathrm{pH}$ until $\mathrm{pH} 12$, the particle size was observed to increase from 162.7 to 2690 d.nm. Supposedly, the particles would scatter when $\mathrm{NaOH}$ was added into the sample due to the negatively charged ions of OH-. However, in Nephelium lappaceum seed with a natural positively charged surface, it would promote aggregation as $\mathrm{NaOH}$ has strong $\mathrm{OH}$-ions that would help to form the inter-bridge between particles [43]. Based on the results of zeta potential and particle size of Nephelium lappaceum seed solution, it can be concluded that it is wise to choose Nephelium lappaceum seed at $\mathrm{pH}$ less than 6 because when the $\mathrm{pH}$ is high ( $\mathrm{pH}$ 7-12), the Nephelium lappaceum seed has negatively charged surface and large particle size. This will affect the coagulation-flocculation process as the negatively charged surface of Nephelium lappaceum seed will repel the negatively charged surface of landfill leachate.

\subsection{Optimum Operating Conditions of Nephelium lappaceum Seed as a Sole Coagulant}

\subsubsection{Optimum $\mathrm{pH}$}

The effect of $\mathrm{pH}$ of Nephelium lappaceum seed as a natural coagulant in the coagulationflocculation process was evaluated. A preliminary test was carried out first on raw leachate by using different dosages (0.5-15 g/L) of Nephelium lappaceum seed to find the predetermined dosage used in determining the optimum $\mathrm{pH}$ of Nephelium lappaceum seed. Figure 7 demonstrates the effect of varying $\mathrm{pH}$ on the coagulation-flocculation process using a pre-determined dose of Nephelium lappaceum seed $(1.5 \mathrm{~g} / \mathrm{L})$ and a pre-determined dosage of Nephelium lappaceum seed $(1.5 \mathrm{~g} / \mathrm{L})$. At pH 2, the removal efficiency of SS, colour, and COD was $96.4 \%, 90.3 \%$, and 56.4\%, respectively. According to Bruice [43], acids are substances that can transfer a proton to a base and are known as proton donors. Therefore, at lower $\mathrm{pH}$, a high concentration of $\mathrm{H}^{+}$due to the hydrolysation of $\mathrm{HCl}$ has neutralised negatively charged particles in the landfill leachate. The charge neutralisation and complex reaction in the process were dominated by hydrogen ions from $\mathrm{HCl}$, and hence, the 
suspension, together with pollutants, began to flocculate [44]. Beyond $\mathrm{pH} 4$, the removals of all parameters were fairly low (less than $30 \%$ ). This could be explained by the fact that Nephelium lappaceum seed naturally has a milky colour. Beyond $\mathrm{pH}$, Nephelium lappaceum seeds also lose the effectiveness to remove SS. This observation could be explained by the fact that the Nephelium lappaceum seed solution has a large particle size and higher SS in the solution, and thus, this has added the quantity of SS in leachate. In conclusion, the Nephelium lappaceum was ineffective when used as the sole coagulant. Nonetheless, pH 6 was observed to be better for all the parameters. In conclusion, the best and optimum $\mathrm{pH}$ value for Nephelium lappaceum seed to remove SS, colour, and COD was at $\mathrm{pH} 6$ whereby it removed $19.2 \%$ COD and $21.8 \%$ colour. Table 3 shows a comparison of previous studies that used natural coagulants in landfill leachate treatment with the current studies.

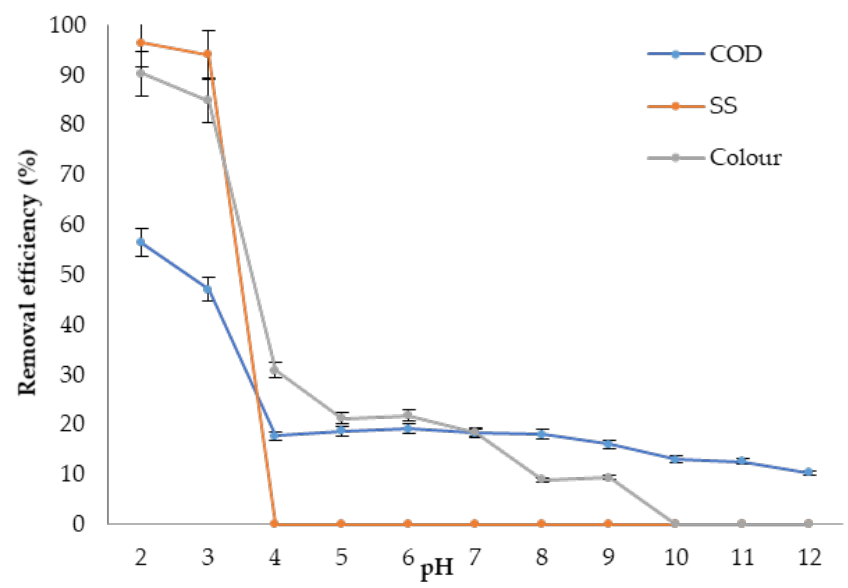

Figure 7. Effect of $\mathrm{pH}$ on pollutant removal using $1.5 \mathrm{~g} / \mathrm{L}$ of Nephelium lappaceum seed dosage.

Table 3. Comparison of previous and current studies for best $\mathrm{pH}$ values of various natural coagulant.

\begin{tabular}{|c|c|c|c|c|c|}
\hline \multirow{2}{*}{ Natural Coagulant } & \multirow{2}{*}{ Optimum pH } & \multicolumn{3}{|c|}{ Pollutant Removal Rate (\%) } & \multirow{2}{*}{ Reference } \\
\hline & & SS & Colour & COD & \\
\hline Commercial sago starch (CSS) & 4 & 29.5 & 15.1 & 28.0 & [37] \\
\hline Chitosan & 4 & - & 14.7 & - & [32] \\
\hline Durian seed starch & 6 & - & 34.0 & - & [45] \\
\hline Tamarindus indica seed (TiS) & 4 & - & 30.2 & 7.5 & [46] \\
\hline Longan seed & 4 & - & 10.3 & 5.2 & [19] \\
\hline Nephelium lappaceum seed & 6 & - & 21.8 & 19.2 & Current Study \\
\hline
\end{tabular}

The bold is to show the results of the current study.

\subsubsection{Optimum Dosage}

After the optimum $\mathrm{pH}$ value was obtained, the optimum dosage of Nephelium lappaceum seed was determined. In this study, various dosages of Nephelium lappaceum seed within the range of 0 to $3 \mathrm{~g} / \mathrm{L}$ were employed to attain the optimum dosage at optimum $\mathrm{pH}$ value, which was $\mathrm{pH} 6$ that was determined earlier. Figure 8 depicts the removal effectiveness for all the parameters. The results demonstrated that COD was the best pollutant removed (35\% reduction at $2 \mathrm{~g} / \mathrm{L})$ by Nephelium lappaceum seed compared to others. The overall performance of Nephelium lappaceum seed alone as a coagulant was considered to be fairly low for all the pollutants. In summary, COD and colour removal were at their maximum performance at dosage $2 \mathrm{~g} / \mathrm{L}$, but Nephelium lappaceum seed could not remove SS from landfill leachate at this dosage, although it could remove $5.6 \%$ of SS at dosage $1 \mathrm{~g} / \mathrm{L}$. Therefore, the best and optimum dosage of Nephelium lappaceum seed to remove the pollutants from landfill leachate was at dosage $2 \mathrm{~g} / \mathrm{L}$. Table 4 displays the comparison of Nephelium lappaceum seed with other natural coagulants from previous studies. 


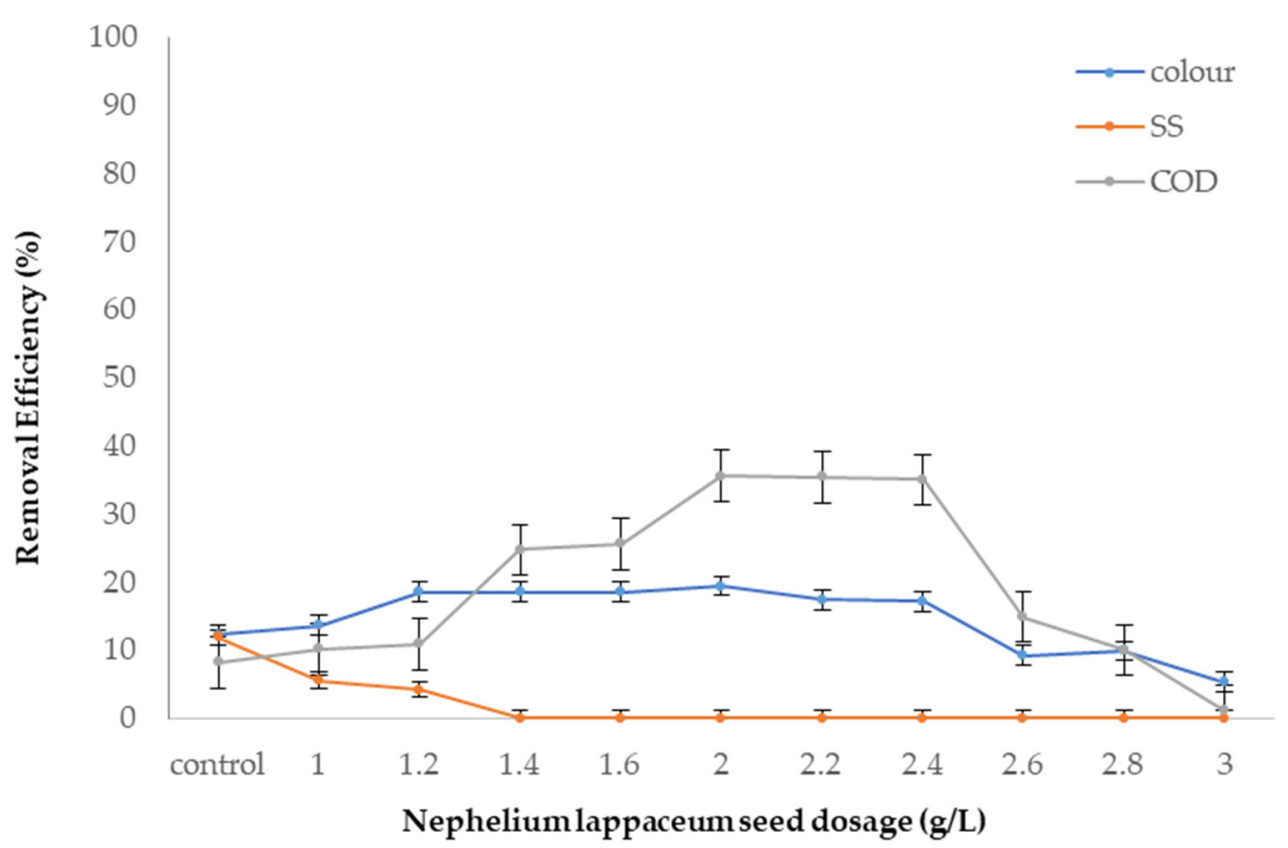

Figure 8. SS, colour, and COD removal efficiency with different dosages of Nephelium lappaceum seed at $\mathrm{pH} 6$.

Table 4. Comparison of optimum dosage of Nephelium lappaceum with other natural coagulants from previous studies.

\begin{tabular}{|c|c|c|c|c|c|}
\hline \multirow{2}{*}{ Natural Coagulant. } & \multirow{2}{*}{ Optimum Dosage (g/L) } & \multicolumn{3}{|c|}{ Pollutant Removal Rate (\%) } & \multirow{2}{*}{ Source } \\
\hline & & SS & Colour & COD & \\
\hline Commercial sago starch & 6 & 29.5 & 15.1 & 28 & [37] \\
\hline Chitosan & 0.06 & - & 14.7 & - & [32] \\
\hline Durian seed starch & 4 & - & 34 & - & [45] \\
\hline Tamarindus indica seed & 5.00 & - & 41.90 & 5.90 & [46] \\
\hline Longan seed & 2.00 & 29.5 & 15.10 & 28.00 & [19] \\
\hline Nephelium lappaceum seed & 2.00 & - & 19.48 & 35.62 & Current Study \\
\hline
\end{tabular}

The bold is to show the results of the current study.

From the comparison above, it can be seen that Nephelium lappaceum seed has the same dosage as Longan seed in removing pollutants, i.e., SS, colour, and COD effectively with medium dosage, whereas other coagulants such as commercial sago starch, durian seed starch, and Tamarindus indica seed needs slightly higher dosages. Nevertheless, among all-natural coagulants, Nephelium lappaceum seed demonstrates the best COD removal in landfill leachate. This is probably due to its positive zeta potential, as well as the presence of biopolymer in the seed that may enhance the inter-particles bridging between the seed and landfill leachate that ensures excellent removal of COD excellently.

\subsection{Optimum Operating Conditions of $\mathrm{SnCl}_{4}$ a Sole Coagulant 3.5.1. Optimum $\mathrm{pH}$}

The effectiveness of $\mathrm{SnCl}_{4}$ at different $\mathrm{pH}$ was investigated with the same procedures as before. Various dosages of $\mathrm{SnCl}_{4}(3.5-17.5 \mathrm{~g} / \mathrm{L})$ were examined. The pre-determined dosage of $\mathrm{SnCl}_{4}$, which was $10.5 \mathrm{~g} / \mathrm{L}$ was employed at a broad range of landfill leachate $\mathrm{pH}$ from 2-12. Based on the results, the highest removal of SS, colour, and COD was noted at $\mathrm{pH} 7$, whereby it removed $98.4 \%$ of SS, $96.8 \%$ of colour, and $8.0 \%$ of COD. According to Coffman [47], inorganic metal salts were normally found between $\mathrm{pH} 5$ to 7 . Yong and Aziz [46] found out that the optimum $\mathrm{pH}$ of PAC was pH 6, and Coffman [47] found that the optimum $\mathrm{pH}$ for titanium dioxide $\left(\mathrm{TiO}_{2}\right)$ was $\mathrm{pH} 5$ for landfill leachate treatment. 


\subsubsection{Optimum Dosage}

After obtaining the optimum $\mathrm{pH}$ value for $\mathrm{SnCl}_{4}$, the dosage of $\mathrm{SnCl}_{4}$ was then determined by using various dosages of $\mathrm{SnCl}_{4}$ within the range of 0 to $17.50 \mathrm{~g} / \mathrm{L}$, and the results are presented in Figure 9. The removals for all the pollutants sharply increased from low dosages until they reached a steady state with $98 \%, 85 \%$ and $83 \%$ reductions of SS, colour and COD, respectively, at $10.5 \mathrm{~g} / \mathrm{L} \mathrm{SnCl}_{4}$. Beyond this point, the removals dropped slightly. This is due to charge reversal, re-dispersal, and re-stabilisation of colloidal particles [43-45] and the overdosage phenomenon where the $\mathrm{SnCl}_{4}$ would cause the particle to re-disperse.

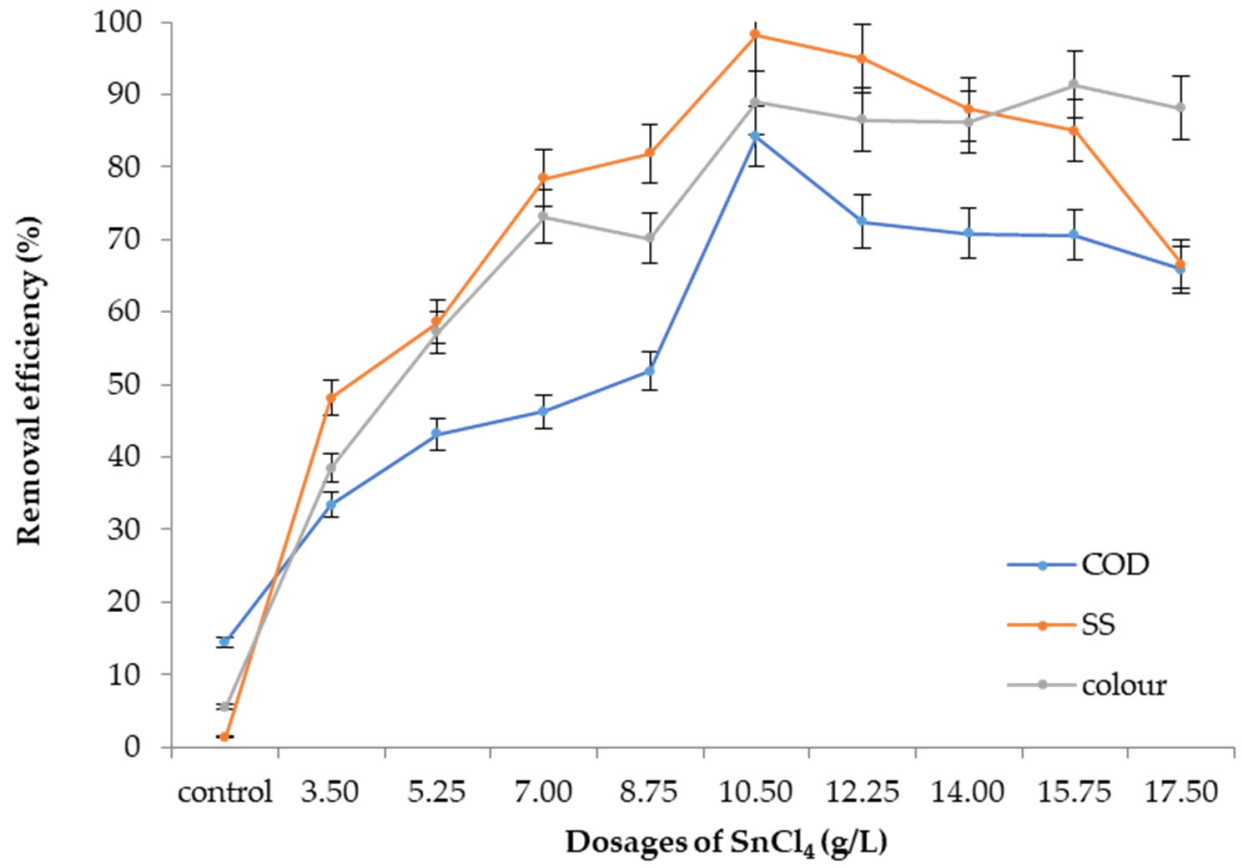

Figure 9. SS, colour, and COD removal efficiency with varied $\mathrm{SnCl}_{4}$ dosages at optimum $\mathrm{pH} 7$.

\subsection{Performance of $\mathrm{SnCl}_{4}$ as a Coagulant and Nephelium lappaceum Seeds as a Flocculant}

$\mathrm{SnCl}_{4}$ was used as a coagulant in this study, with the help of Nephelium lappaceum as a flocculant/coagulant aid. At the same time, the potential of Nephelium lappaceum seed assisting in reducing the coagulant dosages was also tested at a reducing rate from $8.75 \mathrm{~g} / \mathrm{L}$ to $1.0 \mathrm{~g} / \mathrm{L}$ of $\mathrm{SnCl}_{4}$. The efficiency of $\mathrm{SnCl}_{4}$ as a coagulant and Nephelium lappaceum seed as a flocculant was compared to the optimum and best dosage of $\mathrm{SnCl}_{4}$ as a sole coagulant, which was $10.50 \mathrm{~g} / \mathrm{L}$.

Figure 10a illustrates the colour removal efficiency. At $8.40 \mathrm{~g} / \mathrm{L}$ of $\mathrm{SnCl}_{4}$ and $3 \mathrm{~g} / \mathrm{L}$ of Nephelium lappaceum the removal for colour was about $89 \%$. This is just slightly lower than $92 \%$ reduction when $\mathrm{SnCl}_{4}$ was used alone at higher concentrations $(10.5 \mathrm{~g} / \mathrm{L})$. Not much significant difference was noted for SS (Figure 10b), where nearly $90 \%$ reduction was observed compared with $96 \%$ when $\mathrm{SnCl}_{4}$ was used alone. A slight reduction was due to the fact that Nephelium lappaceum seed particles are large in size [48,49], which renders them less effective in removing SS from landfill leachate [50]. Moreover, as discussed earlier, Nephelium lappaceum seed becomes negatively charged after $\mathrm{pH}$ 6. This might affect the particles charge neutralisation. Therefore, the removal of SS from landfill leachate mostly depended on $\mathrm{SnCl}_{4}$. Further lowering of $\mathrm{SnCl}_{4}$ dosages would only cause deterioration in treatment performance [51].

However, for the case of COD (Figure 10c), the performance of Nephelium lappaceum as coagulant aid was not so significant. The removal with and without Nephelium lappaceum was $76 \%$ and $89 \%$, respectively. Generally, introducing Nephelium lappaceum seed 
as a flocculant with increasing dosage resulted in further reduction of COD removal efficiency [52]. This is because Nephelium lappaceum is an organic matter that contributes to the COD readings.

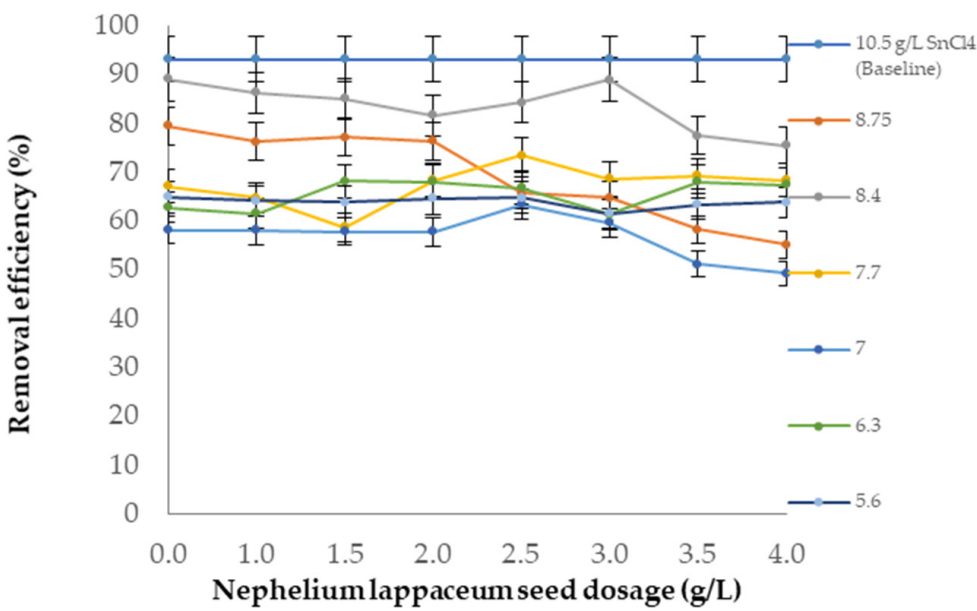

(a)

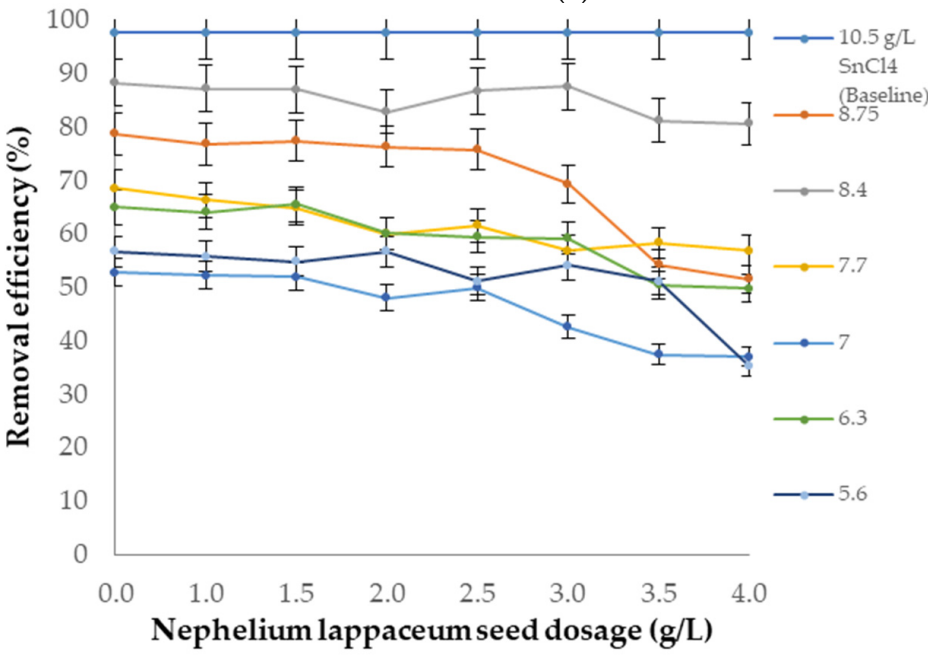

(b)

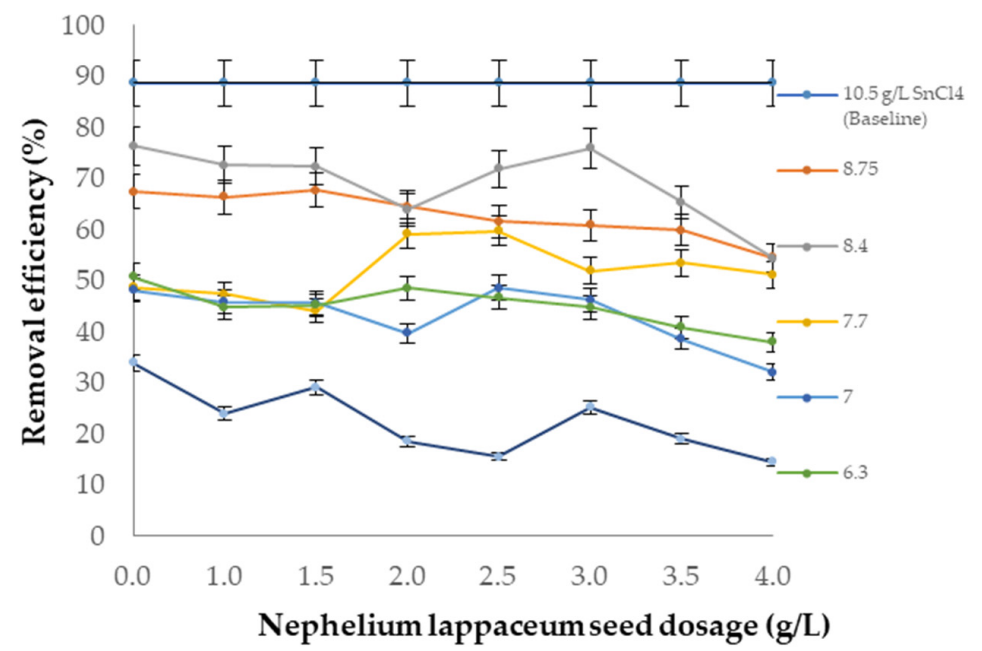

(c)

Figure 10. Removal efficiencies of pollutants at $\mathrm{pH} 7$ with varied dosages of $\mathrm{SnCl}_{4}$ as coagulant and Nephelium lappaceum seed as a flocculant. (a) Colour; (b) Suspended solids (SS); (c) COD. 
The summary of the findings is plotted in Figure 11.

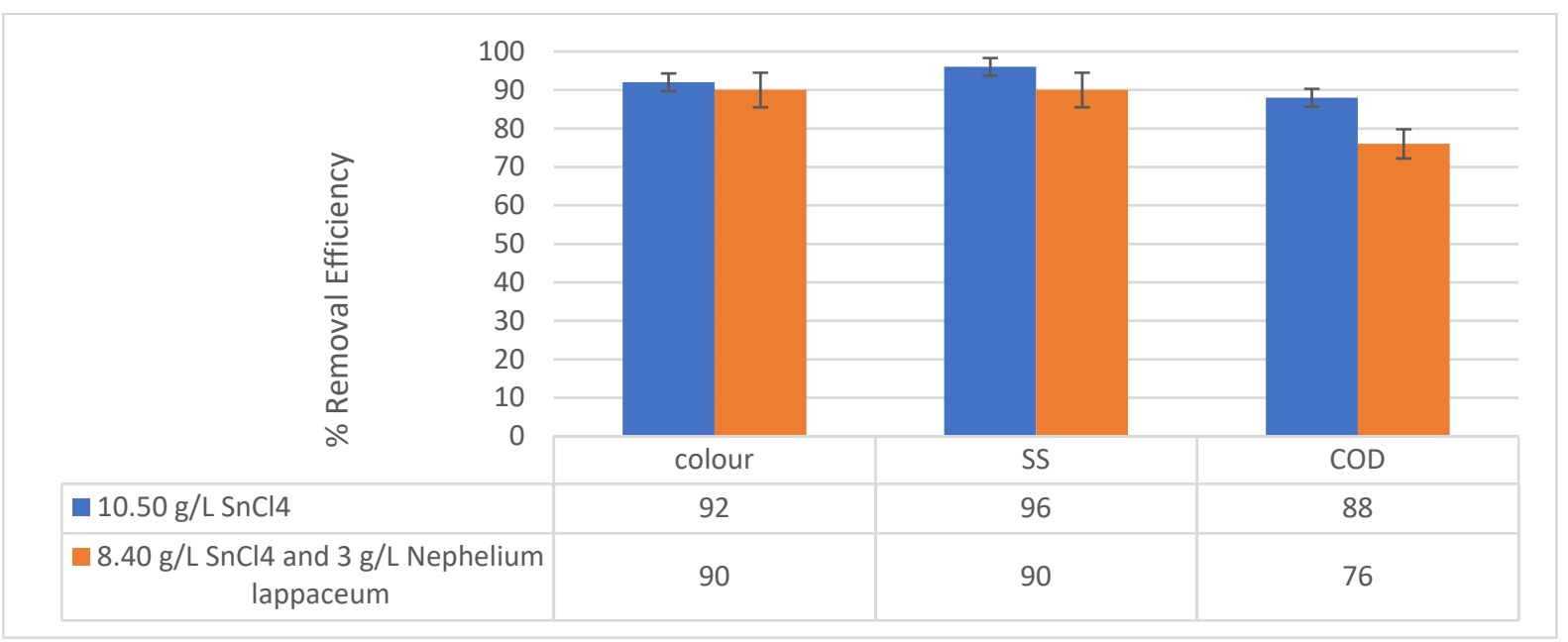

Figure 11. A summary of the removal efficiencies of pollutants conducted at $\mathrm{pH} 7$ with varied dosages of $\mathrm{SnCl}_{4}$ as coagulant and Nephelium lappaceum seed as a flocculant.

\section{Conclusions}

In this study, Nephelium lappaceum seeds were used as an alternative coagulant for leachate treatment and compared with Nephelium lappaceum seeds as a flocculant associated with Tin (IV) chloride $\left(\mathrm{SnCl}_{4}\right)$ as a main coagulant to remove suspended solids (SS), colour, and COD from landfill leachate. Results showed that Nephelium lappaceum was not effective when it was used as a sole coagulant. The best-operating conditions in terms of $\mathrm{pH}$ and dosage were found at $\mathrm{pH} 6$ and $2 \mathrm{~g} / \mathrm{L}$, respectively. The removal of colour and COD were $19.5 \%$ and $35.7 \%$, respectively. At $\mathrm{pH} 7,10.5 \mathrm{~g} / \mathrm{L}$ of $\mathrm{SnCl}_{4}$ exhibited a good performance as a sole coagulant with $98 \%, 85 \%$, and $63 \%$ reductions respectively for SS, colour and COD. At $8.40 \mathrm{~g} / \mathrm{L}$ of $\mathrm{SnCl}_{4}$ and $3 \mathrm{~g} / \mathrm{L}$ of Nephelium lappaceum as flocculant, the removal for colour was about $89 \%$, just slightly lower than $92 \%$ reduction when $\mathrm{SnCl}_{4}$ was used alone. No significant difference was noted for SS where nearly $90 \%$ reduction was observed compared with $96 \%$ when $\mathrm{SnCl}_{4}$ was used alone. However, Nephelium lappaceum as coagulant aid was not so significant for COD. With further investigations and optimisation work, Nephelium lappaceum could be a potential option to be an alternative to metal salt coagulant in treating landfill leachate.

Author Contributions: Conceptualization, methodology, supervision, validation, H.A.A.; data curation, investigation, formal analysis, N.S.R.; writing — original draft preparation, writing-review and editing, M.Y.D.A. All authors have read and agreed to the published version of the manuscript.

Funding: The authors would like to express the highest gratitude to Universiti Sains Malaysia (USM) for the provision of facilities required for this study. This work was also partly funded by the FRGS grant No. FRGS/1/2018/TK01/USM/01/1 and USM RUI grant No. 1001/PAWAM/8014081.

Institutional Review Board Statement: Not applicable.

Informed Consent Statement: Not applicable.

Data Availability Statement: The data presented in this study are available on request from the corresponding author.

Acknowledgments: Thank you is also extended to the Majlis Daerah Kerian (MDK), Perak, for their cooperation during the study and also to the laboratory technical staff who also contributed to the leachate sampling and laboratory works.

Conflicts of Interest: The authors declare no conflict of interest. 


\section{References}

1. Aziz, H.A.; Alias, S.; Assari, F.; Adlan, M.N. The use of alum, ferric chloride and ferrous sulphate as coagulants in removing suspended solids, colour and COD from semi-aerobic landfill leachate at controlled pH. Waste Manag. Res. 2007, 25, 556-565. [CrossRef]

2. Yusoff, M.S.; Aziz, H.A.; Alazaiza, M.Y.; Rui, L.M. Potential use of oil palm trunk starch as coagulant and coagulant aid in semi-aerobic landfill leachate treatment. Water Qual. Res. J. 2019, 54, 203-219. [CrossRef]

3. Zainal, S.F.F.S.; Aziz, H.A.; Omar, F.M.; Alazaiza, M.Y. Influence of Jatropha curcas seeds as a natural flocculant on reducing Tin (IV) tetrachloride in the treatment of concentrated stabilised landfill leachate. Chemosphere 2021, 285, 131484. [CrossRef]

4. Aziz, H.A.; Yusoff, M.S.; Adlan, M.N.; Adnan, N.H.; Alias, S. Physico-chemical removal of iron from semi-aerobic landfill leachate by limestone filter. Waste Manag. 2004, 24, 353-358. [CrossRef]

5. Segundo, I.D.B.; Moreira, F.C.; Silva, T.F.; Webler, A.D.; Boaventura, R.A.; Vilar, V.J. Development of a treatment train for the remediation of a hazardous industrial waste landfill leachate: A big challenge. Sci. Total Environ. 2020, 741, 140165. [CrossRef]

6. Umar, M.; Aziz, H.A.; Yusoff, M.S. Trends in the use of Fenton, electro-Fenton and photo-Fenton for the treatment of landfill leachate. Waste Manag. 2010, 30, 2113-2121. [CrossRef]

7. Nai, C.; Tang, M.; Liu, Y.; Xu, Y.; Dong, L.; Liu, J.; Huang, Q. Potentially contamination and health risk to shallow groundwater caused by closed industrial solid waste landfills: Site reclamation evaluation strategies. J. Clean. Prod. 2021, 286, 125402. [CrossRef]

8. Zainal, S.F.F.S.; Abdul Aziz, H.; Mohd Omar, F.; Alazaiza, M.Y. Sludge performance in coagulation-flocculation treatment for suspended solids removal from landfill leachate using Tin (IV) chloride and Jatropha curcas. Inter. J. Environ. Analyt. Chem. 2021, 1-15. [CrossRef]

9. Wei, Y.; Ye, Y.; Ji, M.; Peng, S.; Qin, F.; Guo, W.; Ngo, H.H. Microbial analysis for the ammonium removal from landfill leachate in an aerobic granular sludge sequencing batch reactor. Bioresour. Technol. 2021, 324, 124639. [CrossRef] [PubMed]

10. Aziz, H.A.; Daud, Z.; Adlan, M.N.; Hung, Y.-T. The use of polyaluminium chloride for removing colour, COD and ammonia from semi-aerobic leachate. Inter. J. Environ. Eng. 2009, 1, 20-35. [CrossRef]

11. Bashir, M.J.; Aziz, H.A.; Yusoff, M.S.; Huqe, A.; Mohajeri, S. Effects of ion exchange resins in different mobile ion forms on semi-aerobic landfill leachate treatment. Water Sci. Technol. 2010, 61, 641-649. [CrossRef]

12. Al-Hamadani, Y.A.; Yusoff, M.S.; Umar, M.; Bashir, M.J.; Adlan, M.N. Application of psyllium husk as coagulant and coagulant aid in semi-aerobic landfill leachate treatment. J. Hazard. Mater. 2011, 190, 582-587. [CrossRef] [PubMed]

13. Yusoff, M.S.; Adam, N.H.; Watalinggam, K.; Aziz, H.A.; Alazaiza, M.Y. Effectiveness of oil palm frond activated carbon for removing COD, color and Fe from landfill leachate. J. Eng. Technol. Sci. 2021, 53, 512-521. [CrossRef]

14. Bashir, M.J.; Aziz, H.A.; Yusoff, M.S. New sequential treatment for mature landfill leachate by cationic/anionic and anionic/cationic processes: Optimisation and comparative study. J. Hazard. Mater. 2011, 186, 92-102. [CrossRef] [PubMed]

15. Aziz, H.A.; AlGburi, H.R.; Alazaiza, M.Y.D.; Noor, A.F.M. Sequential treatment for stabilised landfill leachate by ozonationadsorption and adsorption-ozonation methods. Inter. J. Environ. Sci. Technol. 2021, 18, 861-870.

16. Chiang, L.-C.; Chang, J.-E.; Chung, C.-T. Electrochemical oxidation combined with physical-chemical pre-treatment processes for the treatment of refractory landfill leachate. Environ. Eng. Sci. 2001, 18, 369-379. [CrossRef]

17. Duan, J.; Gregory, J. Coagulation by hydrolysing metal salts. Adv. Coll. Interface Sci. 2003, 100, 475-502. [CrossRef]

18. Kurniawan, T.A.; Lo, W.-H.; Chan, G.Y. Physico-chemical treatments for removal of recalcitrant contaminants from landfill leachate. J. Hazard. Mater. 2006, 129, 80-100. [CrossRef]

19. Aziz, H.A.; Rahim, N.A.; Ramli, S.F.; Alazaiza, M.Y.; Omar, F.M.; Hung, Y.T. Potential use of Dimocarpus longan seeds as a flocculant in landfill leachate treatment. Water 2018, 10, 1672. [CrossRef]

20. Zurina, A.Z.; Mohd Fadzli, M.; Ghani, A.; Abdullah, L. Preliminary study of rambutan (Nephelium lappaceum) seed as potential biocoagulant for turbidity removal. In Advanced Materials Research; Trans Tech Publications Ltd.: Bäch, Switzerland, 2014; Volume 12, pp. 96-105.

21. Aziz, H.A.; Ling, T.J.; Haque, A.A.M.; Umar, M.; Adlan, M.N. Leachate treatment by swim-bed bio fringe technology. Desalination 2011, 276, 278-286. [CrossRef]

22. APAH. Standard Methods for the Examination of Water and Waste Water, 21th ed.; American Public Health Association: Washington, DC, USA, 2005.

23. Thanki, A.; Padhiyar, H.; Kathiriya, T.; Shah, D.; Singh, N.K. Applications of Moringa Oleifera for wastewater treatment: Concepts and approaches. In Green Innovation, Sustainable Development, and Circular Economy; CRC Press: Boca Raton, FL, USA, 2020; Volume 11, pp. 129-140.

24. Chekli, L.; Phuntsho, S.; Kim, J.E.; Kim, J.; Choi, J.Y.; Choi, J.-S. A comprehensive review of hybrid forward osmosis systems: Performance, applications and future prospects. J. Memb. Sci. 2016, 497, 430-449. [CrossRef]

25. Awang, N.A.; Aziz, H.A. Hibiscus rosa-sinensis leaf extract as coagulant aid in leachate treatment. Appl. Water Sci. 2012, 2, 293-298. [CrossRef]

26. Sackey, L.N.A.; Meizah, K. Assesement of the quality of leachate at Sarbah landfill site at Weija in Accra. J. Environ. Chem. Ecotox. 2015, 7, 56-61.

27. Maqbool, F.; Bhatti, Z.; Malik, A.; Pervez, A.; Mahmood, Q. Effect of landfill leachate on the stream water quality. Inter. J. Environ. Res. 2011, 5, 491-500. 
28. Aziz, H.; Yii, Y.; Syed Zainal, S.; Ramli, S.; Akinbile, C. Effects of using Tamarindus indica seeds as a natural coagulant aid in landfill leachate treatment. Global NEST J. 2018, 20, 373-380.

29. Aziz, S.Q.; Aziz, H.A.; Yusoff, M.S.; Bashir, M.J.; Umar, M. Leachate scharacterisation in semi-aerobic and anaerobic sanitary landfills: A comparative study. J. Environ. Manag. 2010, 91, 2608-2614. [CrossRef] [PubMed]

30. Guo, J.-S.; Abbas, A.A.; Chen, Y.-P.; Liu, Z.-P.; Fang, F.; Chen, P. Treatment of landfill leachate using a combined stripping, Fenton, SBR, and coagulation process. J. Hazard. Mater. 2010, 178, 699-705. [CrossRef] [PubMed]

31. Zakaria, S.N.F.; Abdul Aziz, H.; Amr, A.; Salem, S. Performance of ozone $/ \mathrm{ZrCl}_{4}$ oxidation in sstabilised landfill leachate treatment. In Applied Mechanics and Materials; Trans Tech Publications Ltd.: Bäch, Switzerland, 2015; pp. 501-506.

32. Ramli, S.F.; Aziz, H.A.; Omar, F.M.; Yusoff, M.S.; Halim, H.; Kamaruddin, M.A.; Ariffin, K.S.; Hung, Y.T. Reduction of COD and highly coloured mature landfill leachate by tin tetrachloride with rubber seed and polyacrylamide. Water 2021, $13,3062$. [CrossRef]

33. Arenas, M.G.H.; Angel, D.N.; Damian, M.T.M.; Ortiz, D.T.; Díaz, C.N.; Martinez, N.B. Characterization of rambutan (Nephelium lappaceum) fruits from outstanding mexican selections. Rev. Bras. Frutic. 2010, 32, 1098-1104. [CrossRef]

34. Ebeling, J.M.; Rishel, K.L.; Sibrell, P.L. Screening and evaluation of polymers as flocculation aids for the treatment of aquacultural effluents. Aquacultur. Eng. 2005, 33, 235-249. [CrossRef]

35. Zafar, M.S.; Tausif, M.; Mohsin, M.; Ahmad, S.W.; Zia-ul-Haq, M. Potato starch as a coagulant for dye removal from textile wastewater. Water Air Soil Poll. 2015, 226, 244. [CrossRef]

36. Solidum, J. Potential nutritional and medicinal sources from fruit peels in Manila, Philippines. Inter. J. Biosci. Biochem. Bioinform. 2012, 2, 270-274. [CrossRef]

37. Aziz, H.A.; Mohamad Sobri, N.I. Extraction and application of starch-based coagulants from sago trunk for semi-aerobic landfill leachate treatment. J. Environ. Sci. Poll. Res. 2015, 22, 16943-16950. [CrossRef]

38. Mohd-Asharuddin, S.; Othman, N.; Mohd Zin, N.; Tajarudin, H.A. A chemical and morphological study of cassava peel: A potential waste as coagulant aid. In MATEC Web of Conferences; EDP Sciences: Les Ulis, France, 2016; Volume 103.

39. Omar, F.M.; Aziz, H.A.; Stoll, S. Aggregation and disaggregation of ZnO nanoparticles: Influence of $\mathrm{pH}$ and adsorption of Suwannee River humic acid. Sci. Total Environ. 2014, 468, 195-201. [CrossRef]

40. Ab Ghani, Z.; Yusoff, M.S.; Zaman, N.Q.; Zamri, M.F.M.A.; Andas, J. Optimization of preparation conditions for activated carbon from banana pseudo-stem using response surface methodology on removal of color and COD from landfill leachate. Waste Manag. 2017, 62, 177-187. [CrossRef] [PubMed]

41. Cao, B.; Gao, B.; Xu, C.; Fu, Y.; Liu, X. Effects of pH on coagulation behavior and floc properties in Yellow River water treatment using ferric based coagulants. Chin. Sci. Bulletin. 2010, 55, 1382-1387. [CrossRef]

42. Kruszewski, S.; Cyrankiewicz, M. Aggregated silver sols as SERS substrates. Acta Phys. Pol. Ser. A Gen. Phys. 2012, 121, A68. [CrossRef]

43. Borja, K.; Mercado, J.; Combatt, E. Methods of mechanical dispersion for determining granulometric fractions in soils using four dispersant solutions. Agron. Colomb. 2015, 33, 253-260. [CrossRef]

44. Bruice, P.Y. Organic Chemistry: Pearson New International Edition; Pearson Education Limited: New York, NY, USA, 2014.

45. Mishra, A.; Bajpai, M. The flocculation performance of Tamarindus mucilage in relation to removal of vat and direct dyes. Bioresour. Technol. 2006, 97, 1055-1059. [CrossRef] [PubMed]

46. Muaz, M.; Yusof, M.S.; Aziz, H.A. The study of flocculant characteristics for landfill leachate treatment using starch based flocculant from Durio zibethinus seed. Adv. Environ. Biol. 2014, 8, 129-135.

47. Yong, C.; Aziz, H. Utilisation of Tamarindus Indica Seed as Natural Coagulant/Flocculant in Landfill Leachate Treatment. Master's Thesis, Universiti Sains Malaysia, Nibong Tebal, Malaysia, 2016. (unpublished).

48. Coffman, N. Recovering Titanium Dioxide $\left(\mathrm{TiO}_{2}\right)$ after Its Useto Treat Leachate for Reuse on Future Leachate Flows; Florida Atlantic University: Boca Raton, FL, USA, 2015.

49. Badrus, Z. Potential of natural flocculant in coagulation-flocculation wastewater treatment process. In E3S Web of Conferences; EDP Sciences: Les Ulis, France, 2018; p. 05006.

50. Baghvand, A.; Zand, A.D.; Mehrdadi, N.; Karbassi, A. Optimising coagulation process for low to high turbidity waters using aluminum and iron salts. Am. J. Environ. Sci. 2010, 6, 442-448. [CrossRef]

51. Osei, J.A. Utilization of Agricultural Food Waste Products for Bioethanol Generation, Kiambu County, Kenya. Ph.D. Thesis, Kenyatta University, Nairobi, Kenya, 2021.

52. Kalyanasundaram, K. Photochemical applications of solar energy: Photocatalysis and photodecomposition of. Photochemistry 2013, 41, 182. 